\title{
Revista \\ Brasileira

\section{Religiosity and spirituality as resilience strategies among long-living older adults in their daily lives}

\author{
Religiosidade e espiritualidade nas estratégias de resiliência do idoso longevo no cotidiano \\ Religiosidad y espiritualidad como estrategias de resiliencia del anciano en la vida diaria
}

\section{Luana Araújo dos Reis', Tânia Maria de Oliva Menezes'}

'Universidade Federal da Bahia, School of Nursing, Postgraduate Program in Nursing. Salvador, Bahia, Brazil.

How to cite this article:

Reis LA, Menezes TMO. Religiosity and spirituality as resilience strategies among long-living older adults in their daily lives. Rev Bras Enferm [Internet]. 2017;70(4):761-6. [Thematic Edition "Good Practices: Fundamentals of care in Gerontological Nursing”] DOI: http://dx.doi.org/10.1590/0034-7167-2016-0630

Submission: 01-25-2017 Approval: 04-03-2017

\begin{abstract}
Objective: to investigate religiosity and spirituality as a resilience strategy for the long-living older adults in their daily lives. Method: Qualitative research of phenomenological approach based on Martin Heidegger thoughts. Interviews were conducted with 14 older adults registered at a family health unit in the city of Jequié, BA, Brazil. The data were analyzed in the light of Being and Time. Results: The results revealed that God occupies a central position in their lives, and the reading of the bible, praying the rosary and prayers are resilience strategies used for coping with unfavorable situations, recovery and/or maintenance of health, personal and family protection, and, above all, the experience of a satisfactory aging. Final considerations: Religiosity and spirituality were presented as an important resilience strategy in the existence of older adults, showing that through them it is possible to achieve well-being and cope with health and social problems.
\end{abstract}

Descriptors: Aged; Longevity; Religious Personnel; Spirituality; Nursing.

\section{RESUMO}

Objetivo: Desvelar a religiosidade e espiritualidade nas estratégias de resiliência do idoso longevo no cotidiano. Métodos: Pesquisa qualitativa de abordagem fenomenológica fundamentada no pensamento de Martin Heidegger. Foram realizadas entrevistas com 14 pessoas idosas longevas cadastradas em uma unidade de saúde da família no município de Jequié, BA, Brasil. Os dados foram analisados à luz de Ser e Tempo. Resultados: Desvelaram que Deus ocupa uma posição central em suas vidas, e a leitura da bíblia, a reza do terço e a oração são estratégias de resiliência utilizadas para o enfretamento de situações desfavoráveis, a recuperação e/ ou manutenção da saúde, a proteção pessoal e familiar e, sobretudo, a vivência de uma velhice satisfatória. Considerações finais: A religiosidade e espiritualidade foram desveladas como importante estratégia de resiliência no existir da pessoa idosa longeva, sinalizando que, por meio dela, é possível alcançar o bem-estar e enfrentar problemas de saúde e sociais.

Descritores: Idoso; Longevidade; Religiosidade; Espiritualidade; Enfermagem.

\section{RESUMEN}

Objetivo: Develar la religiosidad y la espiritualidad como estrategias de resiliencia del anciano en la vida diaria. Métodos: Investigación cualitativa de abordaje fenomenológica fundamentada en el pensamiento de Martin Heidegger. Se entrevistaron 14 personas mayores longevas registradas en una unidad de salud de la familia del municipio de Jequié, Bahía, Brasil. Los datos se analizaron a la luz de Ser y Tiempo. Resultados: Dios ocupa una posición central en sus vidas y la lectura de la biblia, el rezo del Rosario y la oración son estrategias de resiliencia utilizadas para enfrentar situaciones desfavorables, para recuperar y/o mantener la salud, la protección personal y familiar y, sobretodo, la vivencia de una vejez satisfactoria. Consideraciones finales: La religiosidad y la espiritualidad son importantes como estrategias de resiliencia en la existencia del anciano, ya que a través de ellas alcanza el bienestar y consigue enfrentar problemas sociales y de salud.

Descriptores: Anciano; Longevidad; Religiosidad; Espiritualidad; Enfermería. 


\section{INTRODUCTION}

The increase in the older adults population is a phenomenon all over the world ${ }^{(1-2)}$. The global demographic transition shows a considerable increase in the proportion of older adults aged 80 years or more, which has important implications, especially for the health care area, due to a higher frequency of comorbidities and a higher incidence of functional decline ${ }^{(3)}$.

In Brazil, it is not different. The latest demographic census indicates that the country has a total of 204,450,649 people; of these, $11.71 \%$ are aged 60 years or older, and $1.63 \%$ of the Brazilian population is in the age group of 80 years or more. By 2030, the projection for Brazil is of a 223,126,917 inhabitants, with $17.98 \%$ being older than 60 years and $2.29 \%$ of the country's total population of long-lived elderly people ${ }^{(4)}$.

In this scenario, with the increase in life expectancy, older adults seek strategies to confront the health-disease process, searching for a better quality of life (QoL) and well-being. Coping strategies are defined as "resilience", which is related to the capacity for recovering and healthily adaption in the face of damages, adversities and stressors ${ }^{(5)}$.

In this context, with advancing age, religiosity and spirituality become an important tool for emotional support, which has important effects on physical and mental health ${ }^{(6)}$. These aspects are considered a sociocultural dimension part of the network of meanings created by man to give meaning to life and death, and also exert a significant influence on health care, which is being constructed through time ${ }^{(7)}$.

The relationship between spirituality and older age is due to the capacity to withstand limitations, difficulties and losses inherent to the aging process, with the experience of spirituality having importance and relevance for a good life in old age ${ }^{(8)}$. Religiousness is seen as a form of help and protection from the stress of the losses and modifications that occur during the aging process ${ }^{(9)}$.

Spirituality and religiosity are incentives for facing the challenging situations and difficulties present in the last years of a person's life. Thus, despite their conceptual differences, both are used as resilience strategies and reveal surprising influences on the better QoL of the older adults ${ }^{(10)}$.

In view of the above, the study aimed to investigate religiosity and spirituality as resilience strategies for the long-living older adults in their daily lives.

\section{METHOD}

\section{Ethical aspects}

Since it is a research involving human beings, this study was developed according to the ethical principles of human research according to Resolution 466/2012 of 12/12/2012, of the National Research Ethics Council(11), and the reports were collected after approval of the Research Ethics Committee of the School of Nursing at the Universidade Federal da Bahia.

\section{Type of study}

This is a qualitative research with a phenomenological approach based on Martin Heidegger's thoughts ${ }^{(12)}$ The phenomenological approach suits the object of study, because it allows addressing the phenomenon without making presuppositions that can interfere in the analysis of the results.

This study is part of the doctoral thesis "Meanings of religiosity and spirituality in the life of the long-living older adults", presented to the Graduate Program in Nursing, School of Nursing, Universidade Federal da Bahia - EEUFBA.

\section{Study setting}

The study was conducted at a Family Health Unit (FHU) in the city of Jequié, located in the southwestern region of the state of Bahia, Brazil, from December 2014 to April 2015.

The FHU selected is located in a peripheral neighborhood of the city, where a Family Health Team consisting of a nurse, a physician, a dentist, two nursing technicians and six community health agents operates. The choice for this FHU was made considering the large number of older adults registered and monitored, composing a total of 56 older adults.

\section{Study participants}

A total of 14 older adults registered in the unit were included. The choice for the participants was based on the following criteria: 1) Inclusion: men and women 80 years of age or older, in good conditions to answer the interview; 2) Exclusion: not finding the older adult after three attempts to visit their household; illness during the period of data collection. There was no refusal to participate in the research and no withdrawal.

In order to approach the older adult, the Community Health Agents (CHA) helped out, carrying out a survey with the participants of the research, facilitating the development of workshops and lectures on topics of interest to this group - hypertension, diabetes and coronary diseases - and accompanying the researcher during home visits, with the purpose of providing an opportunity to approach the research participants. From then on, the researcher invited them to participate in the study, scheduling individual meetings to interview them.

\section{Data collection and organization}

The technique used for data collection was the open interview, one of the most used techniques in phenomenological research, containing a triggering question: What do religiosity and spirituality mean in your life? The interviews took place in the older adults' household, in a private space, which ensured the privacy and confidentiality of the information, on previously scheduled days and were recorded by a MP4 electronic device and later fully transcribed. They were conducted in a single meeting with each participant, with an average duration of 24.18 minutes.

\section{Discourse analysis}

In order to systematize and understand the discourses obtained in the interviews with the participants, the steps proposed by Martin Heidegger were followed, throughout the two moments: ontic and hermeneutic circle ${ }^{(12)}$

To support the information obtained during the participants' interviews, we adopted a computational support tool for analysis. This is the qualitative data processing software QSR NVivo ${ }^{\circledR}$, version 11.3 , hereinafter referred to as NVivo. 
This tool helps handling and organizing the data, facilitating the integration process between the units of meaning, for a better understanding of the researcher.

\section{RESULTS}

\section{Characterization of the long-living older adults in the study}

The older adults interviewed are characterized by being between 80 and 104 years old, mostly women (85.7\%). Regarding marital status, $92.8 \%$ do not live with their partners, being widowed or divorced. The level of education ranged from illiterate to complete secondary education. The average monthly income ranged from 1 to 3 minimum salaries. Regarding caregiver assistance at home, most older adults reported not having a caregiver $(42.8 \%), 35.7 \%$ had the assistance of an informal caregiver, and $21.4 \%$ had a formal caregiver.

The testimonies evidenced religiosity and spirituality as important resilience strategies used by older adults in their daily lives, as presented in the following unit.

Faith in God, through prayer, provides tranquility, peace, overcome of adversities, maintenance of health and longevity

The presence of a higher being felt in the daily life of the older adults gives them the belief that they are not helpless, even in the absence of relatives, because faith, expressed through prayer, fills the existential void, providing tranquility and inner peace, as according to their discourses.

I sometimes cry a lot when I see myself alone at home, I get sad because my life was very joyful, I used to walk, but my life now is very sad. [...] when I'm here in the house alone, I get my rosary and I pray, it helps me so much! It gives me some relief. I think that my prayers, the rosaries that I pray, the office of Our Lady, give me strength to do all this. (E8 Woman; 80 years old)

I read the prayer of my guardian angel, a beautiful prayer, I feel so protected! It is what holds me, my daughter, what gives me strength to live: It is faith! Sometimes I am afraid even from my shadow, but I hold on to God. And I really do, I trust God blindly. (E10 - Woman; 80 years old)

E-8 and E-10 discourses reveal that loneliness reminds them of the possibility of existence in the "concern" with the relationship with God. Being alone in old age makes the longliving older adults to have the sense of loneliness diminished by the existence of a shared world with God.

The co-presence felt by the long-living older adult with God enables the Being-alongside in the world, in which God's presence brings peace, security and diminishes the existential void caused by the absence of children, family and friends.

We have to hold on to God, to get there. (E6 - Man, 82 years old)

In the morning, I do not have breakfast without reading a verse. Sometimes sadness comes, because every family has barriers, has flaws, many flaws. But, we only have to keep faith in our heart that one day we win, it can take long, but we win. That's the faith I have! It is faith that moves the mountains. (E11 - Woman; 82 years old)

Today I have nothing, but only having the grace of God is everything in our life. Believing in God, that He is the all-powerful, that he is with us, helps us is everything. I read the Bible, I pray at home. My faith helps me in everything. Because, if it were not for my faith, I wouldn't be who I am today. I live at home unconcerned. (E14 - Woman; 80 years old)

The discourses above reveal the belief in God as means to live an unconcerned old age and cope with unfavorable situations, showing that faith is what gives them support in their daily life. Prayer, as an important resilience strategy for the older adult, is reaffirmed in the testimonies. Gratitude for the blessings achieved, such as the maintained health and longevity, stand out in the testimonies of faith in God.

At bedtime, I read the Bible and pray. God helps and gives me health! We heal. With a prayer, I heal. It is faith, faith renews. (E4 - Woman; 87 years old)

E4 statement shows that through faith, lived through the reading of the Bible and prayer, it is possible to experience tranquility in daily life, as well as to heal from the illnesses of the aging process, reaffirming the manifestation of the power of the faith in God.

I had breast cancer, for me it was the same as not removing anything. Thank God I'm alive to this day. (E1 - Woman, 91 years old)

I believe in God and that's it, I think the faith we have in Him also helps a lot, right? (E2 - Woman, 83 years old)

There are times when I'm kind of sad, I get the Bible, sit down and read. I think it helps my health and my family. (E5 - Woman; 93 years old)

I ask, He (God) helps, He gives me health, happiness, releases me from what is bad. Every night, I talk to Him. When I wake up, I only remember God and I talk to Him. So I have health, happiness. (E7 - Man; 104 years old)

E5 and E7 express that reading the Bible and prayer are resources that enable communication with God and, consequently, the attainment of graces. God presents himself to the older adult as a possibility of maintaining health and happiness, as according to the following testimonies.

I read the bible, it helps me by protecting my children, giving me health. I always get hospitalized and, thank God, I come back safe and sound. It preserves my health. (E12 Woman; 80 years old)

I'm still alive because of the prayers. I always pray. It is difficult, for my health today, there's only God. I live safe in the hands of God, because I have no medicine, my medicine is Christ. There is no time that I am not safe with God. My faith helps me in everything. Just waking up in the morning 
opening my eyes and knowing that I'm alive. Breathing the air. There were many fights, but, thanks God I'm here. I'm here, I'm 85 years old, I've lived a lot, I've seen a lot, I've learned a lot. (E13 - Woman; 85 years old)

When E12 stated that reading the Bible helps to protect her children and restore her health, the manifestation of faith and gratitude can be observed. This faith in God contributes to the confrontation of existential and health problems, which enables experiencing aging in a satisfactory way and reflects in their daily life through well-being.

E12 and E13 discourses reveal that prayer represents to the older adult an expectation of healing and longevity, since, through faith in God, it is possible to live a healthy old age; and through gratitude to God, blessings can be achieved.

Despite some difficulties evidenced by the deponents to live the religiosity, prayer is maintained, according to E13:

Some days I read the Bible, some I don't. But I always pray. I can't read much because I have a vision problem and the Bible has really small letters. So I can't read a lot. Everything is our God. (E13 - Woman, 85 years old)

The resilience strategies used in the daily life of the elderly person are shown on the "cloud of words" (Figure 1), which expresses the essence of the testimonies, revealing religiosity and spirituality.

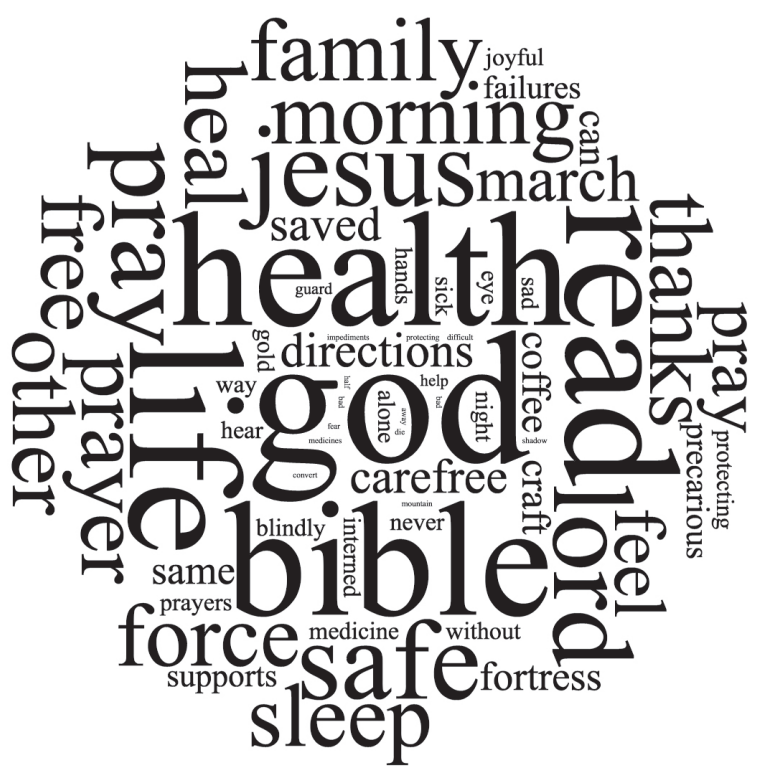

Figure 1 - Word cloud by frequency of words in the node coding "religiosity and spirituality in the resilience strategies long-living older adults daily life", through QSR NVivo

From Figure 1 we can infer that, according to the frequency of the words presented in the discourses of the older adults in this study, God occupies a central position in their lives; and religiosity and spirituality, through the reading of the bible, praying with the rosary and prayer in general, are resilience strategies used in their everyday life to cope with unfavorable situations, recovering and/or maintain health, also to get personal and family protection and, above all, live a peaceful old age.

\section{DISCUSSION}

The unveiling of the essence of the phenomenon, that is, the understanding of the phenomenon as it is - the lifeworld - was possible through the overall vague understanding gained from the statements of older adults being in the world, that revealed the possibility of being in the world of the fourth age, in their daily life, and in their living of religiosity and spirituality, presented as an important resilience strategy.

While being in the world, an older adult can manifest diverse possibilities of being ${ }^{(12)}$, which reveal themselves through "care", part of their daily life via the demonstration of their faith. Their religious and spiritual practices, revealed in the testimonies of their day-to-day lives, show the strong connection between the long-living older adults and God.

The statements revealed that faith in God is important in the life of the older adult, as is reading the Bible, praying the rosary and prayers.

In this way, the long-living older adults' being, when revealing in their discourse their daily life, allow us to perceive the being-in-the-world-of-care and presents faith in God as one of the possibilities of Being, since it is a fundamental element to live with tranquility and reach longevity. The Presence is with and in the world of occupations ${ }^{(12)}$.

The way of being of care occurs in the daily relationship that the long-living older adults maintain with God, that is, it occurs only through the contact necessary to maintain their well-being, such as the reading of the Bible and prayer. The older adult uses religiousness and spirituality in order "bealongside-with". Once apparent, they give themselves into the "World" and fall back into religiousness ${ }^{(12)}$.

The absence of children, the advancement of age, and the functional limitations make the long-living older adult be in others ways of being, here shown through the living of religiosity and spirituality as a possibility of existence. For Heiddeger ${ }^{(12)}$, the everyday Being-in-the-World of circumspection needs the possibility of sight, or in other words, clearing to be able to take charge in occupation with what is Present-athand, by means of which is simply present.

The long-living older adults, whilst being-alongside, due to the absence of relatives, reveal their own or authentic way of being through being alone, seeing that religiousness and spirituality are revealed in their Facticity, in their occupation (being-alongside). Even being alone in presence, they are being-alongside in the World. only in a Being-alongside and for a Being-alongside that the other may be missed. The Being-alone is a deficient way of Being-alongside, and its possibility is proof of this ${ }^{(12)}$.

A study conducted in São Paulo, Brazil - with twelve older adults with ages between 61 and 93 years of age (with a mean of 73.92), with the aim to identify the meanings of Religion and Religiousness, as well as the relationship between aging and spirituality - revealed that all of the older adults questioned, 
recognized the importance of spirituality in their lives. This is experienced in this phase of life through the satisfaction of living it in a continuous form, as their lives do not grow in importance, but in maturing and a deepening of their living(8).

The connection with God or the higher power is considered a key-component in spirituality, being associated with the "self" and one's way of being in the world ${ }^{(13)}$. Spiritual practices, while altering the brain's neural chemistry, offer a sense of peace, safety and happiness, and reduce anxiety, stress and depression ${ }^{(14)}$.

Religious practice helps to reduce anxiety, increase hopes, and opens doors to the immenseness and the meaning of existence. The offerings and prayers can be either a way of giving thanks or asking for help, made silently or out loud, and with either a happy or a heavy heart. It is an uplifting experience, as there is the need to give thanks to God for everything anyhow ${ }^{(6)}$.

Some behaviors and religious or spiritual beliefs are directly related to the overall happiness and health, since they discourage unhealthy habits which then contributes to a successful aging ${ }^{(15)}$.

The searches for divine protection keep God in a relationship of being together, and or, being-with the long-living older adults. In this relationship, worry is lived by the Being in the world, it is the involvement of the presence with other presences, only possible through a close and meaningful relationship.

For Heidegger ${ }^{(12)}$, there is no man without the World, nor is there a man without Dasein, Being-there; presence. Man is Beingin and Being-alongside the World. We are inserted in the World; in a way, we were thrown into the World; because of this, Dasein is a Being-in-the-world ${ }^{(12)}$. Therefore, the long-living older adult, by the realization of their faith in God, reveal themselves as Beingin and Being-alongside religiousness and spirituality.

Religious faith and spirituality have helped in the acceptance of negative results related to the onset of chronic illnesses, helping many to find meaning for that situation or even interpret them as part of God's greater plan. Spirituality, as a means of confronting, is capable of alleviating pain, psychological stress, and very often, the feeling of giving up ${ }^{(16)}$.

For the older adults, maintaining religiousness and spirituality is a resource for standing up to stressful events, such as: financial losses after retirement; loss of youth, vigor and looks; the loss of health and the increase of chronic illnesses; the loss of independence and autonomy; the loss of close relatives and friends; and the certainty of life's end ${ }^{(17)}$.

A study conducted in Minas Gerais in Brazil with six elderly men, with the objective of understanding the meanings produced by the older adult over their personal resources for a successful aging, revealed that the subjects interviewed associated success in the process of aging with religiousness and spirituality, indicated by them as external facilitators of a positive aging ${ }^{(18)}$.
The long-living older adults lives in an authentic way the facticity when they continue their prayers at home and recognize that, despite enjoying reading the Bible, they cannot be reading too small prints. Being authentic, the long-living older adult can find an important resilience strategy in religiousness and spirituality, which can give new meaning to their lives. The being revealed is a way of being an entity which always is itself and its possibilities ${ }^{(12)}$.

The possibilities of being of the older adults present themselves in various ways, in agreement with the Worldness of the World. For Heidegger (12), "worldness" means the structure of the moment of Being-in-the-world. Therefore, the older adult must be open to new ways of being, seeking new possibilities and meanings to their lives.

A study conducted in Bahia, Brazil, revealed the importance that professionals can give to the care given to the elderly, evaluating the spiritual needs of this specific group, looking to improve their health-related QoL. It was stated that religiousness as a therapeutic tool is compatible with mental and physical well-being, allowing a better quality of life for older adults ${ }^{(19)}$.

\section{Limitation of the study}

The limitation of this study is related to non-generalization Of their results for the entire population, since they represent Elderly people registered in a USF In the interior of Bahia. However, the results can be Applied to individuals experiencing situations similar to those Of our participants.

\section{Contributions to the area of nursing}

The results of this study are available so that health professionals, in particular nurses, might reflect upon the care of the older adult in several scenarios, with a view to value their religiousness and spirituality, so that a more humanistic care can be achieved, which may consider not only biological aspects, but also the spiritual dimension, which should also be respected and valued.

\section{FINAL CONSIDERATIONS}

Religiosity and spirituality were presented as important resilience strategies in the existence of the long-living older adults, contributing to coping with pathologies, loneliness, and other significant demands that may decrease the wellbeing of this population.

\section{FUNDING}

Coordination for the Improvement of Higher Education Personnel (CAPES), which granted the PhD scholarship for Luana Araújo dos Reis.

\section{REFERENCES}

1. Fernández-Ballesteros R, Robine JM, Walker A, Kalache A. Active Aging: a global goal. Current Gerontol Geriat Res [Internet]. 2013 [cited 2016 Nov 22];4p. Available from: https://www.hindawi.com/journals/cggr/2013/298012/.

2. Tavares DMS, Dias FA. Functional capacity, morbidities and quality of life of the elderly. Texto Contexto Enferm [Internet]. 2012 [cited 2016 Nov 22];21(1):112-20. Available from: http://www.scielo.br/pdf/tce/v21n1/en_a13v21n1.pdf 
3. Lourenço TM, Lenardt MH, Kletemberg DF, Seima MD, Tallmann AEC, Neu DKM. Capacidade funcional no idoso longevo: uma revisão integrativa. Rev Gaúcha Enferm [Internet]. 2012 [cited 2016 Nov 22];33(2):176-85. Available from: http://www.scielo.br/ pdf/rgenf/v33n2/25.pdf

4. Brasil. Instituto Brasileiro de Geografia e Estatística (IBGE). Ministério do Planejamento, Orçamento e Gestão Diretoria de Pesquisas. Projeção da população do Brasil e unidades da federação por sexo e idade para o período de 2000 a 2030 [Internet]. Rio de janeiro: IBGE, 2015 [cited 2016 Nov 22]. Available from: http://www.ibge.gov.br/apps/populacao/projecao/.

5. Bhui K. A fine balance in the Science of risk and resilience. Brt J Psych [Internet]. 2014 [cited 2016 Nov 22];204(5):413-4. Available from: http://bjp.rcpsych.org/content/204/5/413

6. Zenevicz L, Moriguchi Y, Madureira VSF. The religiosity in the process of living getting old. Rev Esc Enferm USP [Internet]. 2013 [cited 2016 Nov 22];47(2):427-33. Available from: http://www.scielo.br/pdf/reeusp/v47n2/en 23.pdf

7. Cortez, EA; Teixeira ER. O enfermeiro diante da religiosidade do cliente. Rev Enferm UERJ [Internet]. 2010 [cited 2016 Nov 22];18(1):114-9. Available from: http://www.facenf.uerj.br/v18n1/v18n1a20.pdf

8. Chaves LJ, Gil CA. Older people's concepts of spirituality, related to aging and quality of life. Ciência Saúde Colet [Internet]. 2015 [cited 2016 Nov 27];20(12):3641-52. Available from: http://www.scielosp.org/pdf/csc/v20n12/en_1413-8123-csc-20-12-3641.pdf

9. Costa F, Gottlieb MGV, Moriguchi Y. Religiosity and feelings of loneliness in elderly. Rev Ger Gerontol Aging [Internet]. 2012[cited 2016 Nov 10];6(2):151-66. Available from: http://ggaging.com/details/200/pt-BR/religiosity-and-feelings-of-loneliness-in-elderly Portuguese.

10. Lima BFV. Espiritualidade, Religiosidade e Qualidade de Vida nos Idosos [Dissertação]. Universidade Católica Portuguesa; 2013 [cited 2016 Nov 24]. Available from: http://repositorio.ucp.pt/bitstream/10400.14/15216/1/Tese\%20Barbara.pdf

11. Brasil. Resolução $n^{\circ} 466$ de 12 de dezembro de 2012. Aprova as diretrizes e normas regulamentadoras de pesquisas envolvendo seres humanos[Internet]. Conselho Nacional de Saúde. Brasília. 2012 [cited 2016 Nov 22]. Available from: http://conselho.saude. gov.br/resolucoes/2012/Reso466.pdf

12. Heidegger M. Ser e Tempo. Petrópolis (RJ): Vozes. 8 ed. 2013, p.600.

13. Gall TL, Malette J, Guirguis-Younger M. Spirituality and religiousness: a diversity of definitions. J Spiritual Mental Health [Internet]. 2011 [cited 2016 Nov 27];13(3):158-81. Available from: https://www.researchgate.net/journal/1934-9637_Journal_of_Spirituality_in_Mental_Health

14. Falconi Filho A. Perda de Pessoas amadas. Editora EME, Capivari (SP), 2011.

15. Tovar-Murray D. The multiple determinants of religious behaviors and spiritual beliefs on well-being. J Spiritual Mental Health [Internet]. 2011 [cited 2016 Nov 24];13(3):182-92. Available from: http://www.tandfonline.com/doi/full/10.1080/19349637.201 1.593405 ? scroll $=$ top\&needAccess $=$ true

16. Rocha ACAL. A espiritualidade no manejo da doença crônica do idoso[Dissertação]. Escola de Enfermagem da Universidade de São Paulo, São Paulo, 2011 [cited 2016 Nov 24]. 85f. Available from: http://www.teses.usp.br/teses/disponiveis/7/7141/tde-29112011-152813/pt-br. php

17. Duarte FM, Wanderley KS. Religion and spirituality of elderly living in a geriatrics ward. Psic: Teor e Pesq [Internet]. 2011 [cited 2016 Nov 22];27(1):49-53. Available from: http://www.scielo.br/pdf/ptp/v27n1/a07v27n1.pdf

18. Santos ST, Souza LV. Envelhecimento positivo como construção social: práticas discursivas de homens com mais de sessenta anos. Rev SPAGESP [Internet]. 2015 [cited 2016 Nov 22];16(2):46-58. Available from: http://pepsic.bvsalud.org/pdf/rspagesp/v16n2/ v16n2a05.pdf

19. Santos NC, Abdala GA. Religiosity and health-related quality of life of elderly in a city in Bahia, Brazil. Rev Bras Geriatr Gerontol [Internet]. 2014 [cited 2016 Nov 22];17(4):795-80. Available from: http://www.scielo.br/pdf/rbgg/v17n4/1809-9823-rbgg-17-04-00795.pdf 